\title{
IAMJ
}

INTERNATIONAL

AYURVEDIC

MEDICAL JOURNAL

ISSN: 23205091

Impact Factor: 5.344

\section{ROLE OF AYURVEDA AND YOGA FOR COVID-19}

\author{
Priyanka $^{1}$, Yogesh Jakhar ${ }^{2}$, Anupam Pathak ${ }^{3}$ \\ ${ }^{1}$ PG Scholar Dept of Swasthvritta, ${ }^{2}$ Assistant Professor, ${ }^{3}$ Professor \\ Dept of Swasthvritta, Sriganganagar College of Ayurvedic Sciences \& Hospital, Tantia University, \\ Sriganganagar - 335001, India
}

Corresponding Author: doc.vashist22@gmail.com

\section{https://doi.org/10.46607/iamj2808082020}

(Published online: August 2020)

Open Access

(C) International Ayurvedic Medical Journal, India 2020

Article Received: 28/07/2020 - Peer Reviewed: 07/08/2020 - Accepted for Publication: 07/08/2020

\section{Check for updates}

\section{ABSTRACT}

The outbreak of Corona virus disease (COVID-19) has been recently declared as Public Health Emergency of International Concern (PHEIC) by World Health Organization and the virus has now spread beyond the boundaries of countries and continents. At present, no specific antiviral treatment or vaccine is available or recommended to counter the COVID-19, and the potential therapy is still symptomatic. The outbreak of the Corona virus was begun in Wuhan, China in December 2019. The most common symptoms are fever, tiredness and dry cough. Some individuals also develop aches and pains, nasal congestion, runny nose, sore throat, or diarrhea. It was reported that traditional remedies may alleviate the symptoms of COVID19. Ayurveda is the world's oldest medical system that can manage any disease without side effects. Ayurveda is equipped with varieties of treatment modalities to handle with any type of deadly diseases. However, a major drawback is a lack of adequate scientific basis. In recent time, a branch of modern medical science has developed and is known as Psycho- Neuro -Immunology. It deals with the phenomenon of how our thoughts and emotions can affect our immune system. Stress, fear and negative emotions are known to weaken our immune system while Yoga (including meditation), mindfulness, positive emotions, and relaxation strengthen it. Yoga plays an important role to strengthen our immune system.

Keyword: Yoga, COVID-19, Pandemic, Ayurveda. 


\section{INTRODUCTION}

The corona virus disease 19 (COVID-19) pandemic is unique and unprecedented in several aspects and has challenged health care systems. At present, the global momentum is unabated, and a second wave is anticipated $^{1}$. The experience and lessons learnt from the earlier severe acute respiratory syndrome (SARS) epidemics appear inadequate and call for better approaches and strategies in public health and medical care. The current prophylactic measures are insufficient, and suggested options such as hydroxychloroquine (HCQ) are still under investigation ${ }^{2,3}$.

The prophylactic and therapeutic potential of traditional and complementary medicine systems such as Ayurveda and Yoga is not really being considered during this crisis and global hunt for effective preventive and treatment measures.

In this commentary, we have attempted to highlight the knowledge from Ayurveda and Yoga that might be effectively utilized in the prophylaxis and adjuvant therapy of COVID-19. Ayurveda and Yoga as an addon therapy that support patients of COVID-19 by improving the quality of standard care.

Research and therapeutic strategies for COVID-19 have focused on agents to attack the virus or immunize against it. This leaves aside the consideration of the host - one of the most important factors in disease dynamics. Ayurveda pays particular attention to the host and recommends measures for a healthy lifestyle rather than the mere prescription of medicine. Charaka Samhita ${ }^{4}$ the classic of Ayurveda, describes epidemic management and defines immunity as the ability to prevent disease and arrest its progress to maintain homeostasis. The concept of building strength of mind and body to cope with various stressors, including infection, is a corner stone of Ayurveda practice. Similar to innate and acquired immunity, the Ayurve$d a$ concept of immunity (Bala or strength) is classified as natural (Sahaja), (Kalaja), and acquired (Yuktikrut). The holistic approach of Ayurveda toward promoting health (Swasthavritta) includes personalized interventions based on host and environmental factors. Local ${ }^{5}$ and systemic ${ }^{6}$ interventions to boost the immune system have been advocated to manage respiratory ill- nesses. The choice of specific Ayurveda therapeutic agents and practices is based on certain individual genetic characteristics known as Dosha Prakriti types (Vata, Pitta, and Kapha $)^{7}$ In our opinion, several general measures described below may be useful to reduce the risk of SARS-COV-2 infection and complement therapeutic management as add-on treatment.

\section{Local Prophylaxis}

The eyes, nose, and mouth are the main portals of entry of droplets carrying the SARS-COV-2. Prior to the final assault in the lungs, the virus gains access to the throat region and stays for some hours. The fatty acid coat of the virus adheres to the moist mucosal layers, which helps it gain entry into the cells by binding to specific cell receptors. Ayurveda classics mention several interventions that are likely to target these entry portals $^{8}$. This may help to improve the innate immunologic response of the mucus membranes and may thus inhibit the virus transmission to the lungs. These measures may hence function as "physiological masks" barricading the viral invasion. The general measures for respiratory illnesses described in Ayurvedic texts ${ }^{9}$. Such as consumption of hot water, hot food, and herbal decoctions, gargling with medicated water, steam inhalation, and local applications may be helpful for symptomatic relief in mild cases.

\section{Medicated water}

Drinking hot or warm water is a popular home remedy for many ailments. Ayurveda also advocates this as a measure for improving digestion of Ama, a proinflammatory product of impaired metabolic disorders. The presence of Ama is linked to increased susceptibility to infections ${ }^{10}$. Traditionally, warm water is consumed in many parts of India for diverse disorders of fever, inflammation, metabolism, and allergy such as rhinitis and asthma. Several spices that are popularly used in the kitchen are added as single or multiple agents to the boiling water and consumed as medication throughout the day. These spices include dry ginger (Zingiber officinale), Yashtimadhu (Glycyrrhiza glabra), and nut-grass (Cyperus rotundus) rhizomes; Khus - Khus (Vetiveria zizanioides) and Indian sarsaparilla (Hemisdesmus indicus) roots; coriander (Cori- 
andrum sativum) and fennel (Cuminum cyminum) seeds; and cinnamon (Cinnamomum verum) and catechu (Acacia catechu) barks ${ }^{11}$.

\section{Mouth rinse and gargle}

Warm liquids and oils are used as gargles (Gandusha) or mouth rinses (Kavala) to cleanse the mouth and throat thoroughly. This can also have a systemic effect $^{12}$. The oils or oily decoctions clean the oral cavity, pharynx, and tonsillar area and are likely to coat the mucosa as biofilm and induce additional immune modulatory, antioxidant, and antimicrobial benefits ${ }^{13}$. Turmeric (Curcuma longa) rhizome, Yashtimadhu or liquorice (Glycyrrhiza glabra) stem, Neem (Azadiracta indica) and Catechu (Acacia arabica) barks, and natural salt may be used to prepare medicated water/solutions for gargles/mouth rinse. Gargles with these medicated decoctions have demonstrated beneficial effects in xerostomia (dry mouth), post-operative sore throat, oral ulcers, gingivitis, and bacterial growth $^{14,15}$. Glycyrrhizin, an active component in liquorice was found to be more effective than common antivirals in inhibiting the replication of SARS virus and inhibited its adsorption and penetration ${ }^{16}$. Yoga texts recommend cleansing of the nasal passage with salt water (Jala Neti) ${ }^{17}$. The efficacy of salt water in upper respiratory infections has been reported in randomized controlled trials (RCTs), although more conclusive evidence is needed ${ }^{18}$.

\section{Nasal oil application}

Ayurveda recommends the application of medicated oils made from butter oil (Ghee) and vegetable oils such as sesame or coconut in the nostrils. This may protect the respiratory tract from pathogen entry. This procedure known as Nasya is well described in Ayur$v e d a^{19}$. Application of pure sesame oil was found to be effective for the treatment of dry nasal mucosa ${ }^{20}$. Similar to gargles and mouth rinses, nasal oil application possibly forms a biofilm and can help as a barrier to the entry of the virus particles. Researchers of Traditional Chinese Medicine have already proposed the use of nasal oil application for preventing SARSCOV-2 infection ${ }^{21}$

\section{Steam inhalation}

Steam inhalation and hot fomentation (with aromatic oils such as menthol) provide satisfactory clinical relief in nasal and throat congestion, bronchoconstriction, headache, and sinusitis. Its role in improving nasal conditioning, improving nasal mucus velocity, and reducing congestion and inflammation has been reported in several clinical studies ${ }^{22,23,24}$.

\section{Systemic Prophylaxis}

Ayurveda advocates several non-pharmacological measures that are critical to overall health, including diet, sleep, mental relaxation, lifestyle behavior, and Yoga. Several studies have endorsed the role of Yoga breathing techniques (Pranayama), postures (Asanas), and procedures (Yogic Kriya) in improving lung health and exercise tolerance ${ }^{25,26}$. The recommended daily $\operatorname{diet}^{27}$ includes fresh hot soups of vegetables (radish, trigonella leaves, drum stick vegetable pods) and pulses (lentils, green gram/mung beans, chickpeas) seasoned with spices such as Ginger (Zingiber officinale), Garlic (Allium sativum), Cumin seeds (Cuminum cyminum), and Mustard (Brassica nigra) seeds (black whole mustard).

\section{Yoga for Mental Health}

Poor mental health conditions, including stress and depression, are known to increase the risk of acute respiratory infections ${ }^{28}$. Rising numbers of COVID19 cases and deaths possibly raise stress and anxiety, while loneliness and depressive feelings are likely due to mandatory social distancing measures. Consideration of the mind is another distinction of Ayurveda and Yoga. Several measures for mental health are described, including Pranayama and Meditation. Pranayama is known to improve lung function ${ }^{29}$. Meditation is found to reduce inflammation markers and influence markers of virus-specific immune respons $\mathrm{e}^{30}$. Yoga including meditation could be a simple and useful home-based practice for the prevention and postrecovery management of COVID-19.

\section{DISCUSSION}

Modern medical care and health systems are being tested to the hilt for effective management of COVID19. However, there are several gaps. We must remem- 
ber the basic principle in medicine that "prevention is better than cure.'

The simple and feasible measures based on Ayurveda and Yoga could be quickly advertised in public-health campaigns through electronic and print media and information brochures for public distribution and display at prominent locations. The Ministry of $A Y U S H$, Government of India, has already issued a very useful advisory in this context ${ }^{31}$. People are overstressed by the compulsions of social distancing and physical barrier methods. They are likely to find comfort and support in some of the deeply rooted traditional practices that may protect them from the infection and its associated debilitating conditions. Noticeably, these interventions have the advantages of simplicity, affordability, and acceptability and appear promising as feasible measures for large-scale implementation. Ayurveda, Yoga, and meditation have a potential role to engage the community in creating a more positive health environment. Admittedly, there is need for more research. It was welcome news to learn that the United States National Institutes of Health, National Center for Complementary and Integrative Health has engaged a stress-related initiative and is reportedly considering others ${ }^{32}$. Another timely initiative is the launch of the traditional, complementary, and integrative health and medicine COVID-19 support registry to document practices and products ${ }^{33}$. The evidence presented here should draw the attention of stakeholders, including the World Health Organization, to the unexplored potential of traditional medicine systems and adopting integrative approaches in the search for solutions for the COVID 19 crisis. It is high time to embrace integration with an open mind.

\section{CONCLUSION}

By adding healthy diet and applying Ayurveda and Yoga as an add-on therapy we can improve the quality of standard care.

The practice of Yoga as therapeutic tool during the COVID-19 pandemic may help ensure better physical and mental health among the public. Proper training of Yoga by a skilled teacher and a 30 -minute practice every day will maximize the benefit of this ancient health ritual. Health care providers play a crucial role in encouraging patients to maintain performing Yoga during this challenging time.

\section{REFERENCES}

1. Cyranoski D. "We need to be alert": scientists fear second corona virus wave as China's lockdowns ease. Nature 2020 [E pub ahead of print]; DOI: 10.1038/d41586-020-00938-0.

2. World Health Organization Off label use of medicines for COVID 19. WHO reference number: WHO/2019. nCoV/Sci Brief/Off-label use/2020.1 Online document at: https://apps.who.int/iris/bitstream/handle/10665/33164 0/WHO-2019-nCoV-Sci_Brief-Off-label_use-2020.1eng.pdf, accessed April 8, 2020.

3. World Health Organization WHO SOLIDARITY Clinical trial for COVID 19 treatments. Online document at: https://www.who.int/solidarity-clinical-trial-forcovid-19-treatments, accessed April 8, 2020.

4. Acharya Y, ed. Charaka Samhita. Varanasi, India: Chaukhamba Surbharati, 1992.

5. Chandran S, Dinesh K, Patgiri B, et al. Unique contributions of Keraleeya Ayurveda in pediatric health care. J Ayurveda Integr Med 2018; 9:136-142.

6. Thatte U, Chiplunkar S, Bhalerao S, et al. Immunological and metabolic responses to a therapeutic course of Basti in obesity. Indian J Med Res 2015; 142:53-62.

7. Patwardhan B, Bodeker G. Ayurvedic genomics: establishing a genetic basis for mind-body typologies. J Altern Complement Med 2008; 14:571-576.

8. Paradkar H ed. Ashtanga Hrudaya of Vagbhata. Varanasi, India: Chaukhambha Surbharati Prakashan, 2003:287-294.

9. Acharya YT, ed. Shri Dalhanacharaya Nibandhasamgraha commentary of Sushruta Samhita. Varanasi, India: Chaukumba Sanskrit Sansthan, 2003:761-765.

10. Sumantran VN, Tillu G. Cancer, inflammation and insights from Ayurveda. Evid Based Complement Alternat Med 2012; 2012:306346.

11. Shrungeswara AH, Unnikrishnan MK. Evolution of dietary preferences and the innate urge to heal: drug discovery lessons from Ayurveda. J Ayurveda Integr Med 2019; 10: 222-226.

12. Amruthesh S. Dentistry and Ayurveda-IV: classification and management of common oral diseases. Indian J Dent Res 2008; 19:52-61.

13. Shanbhag VK. Oil pulling for maintaining oral hygiene - a review. J Tradit Complement Med 2017; 7:106109

14. Agarwal A, Gupta D, Yadav G, et al. An evaluation of the efficacy of licorice gargles for attenuating postoperative sore throat: a prospective, randomized, singleblind study. Anesth Analg 2009; 109:77-81. 
15. Vanka A, Tandon S, Rao SR, et al. The effect of indigenous Neem [Azadirachta indica] [correction of (Adirachta indica)] mouth wash on Streptococcus mutans and lactobacilli growth. Indian J Dent Res 2001; 12:133-144.

16. Cinatl J, Morgenstern B, Bauer G, et al. Glycyrrhizin, an active component of liquorice roots, and replication of SARS-associated coronavirus. Lancet 2003; 361:2045-2046.

17. Muktibodhananda S. Hatha Yogo Pradipika. Light on Hatha Yoga. 4th ed. Munger, India: Bihar School of Yoga, 2012: 202-205.

18. King D, Mitchell B, Williams CP, et al. Saline nasal irrigation for acute upper respiratory tract infections. Cochrane Database Syst Rev 2015; 4:CD006821.

19. Vinjamury SP, Vinjamury M, Sucharitakul S, et al. Panchakarma: Ayurvedic detoxification and allied therapies--is there any evidence? In: Evidence-Based Practice in Complementary and Alternative Medicine. Berlin: Springer, 2012:113-137.

20. Johnsen J, Bratt B, Michel-Barron O, et al. Pure sesame oil vs isotonic sodium chloride solution as treatment for dry nasal mucosa. Arch Otolaryngol Head Neck Surg 2001; 127:1353-1356.

21. Fan W, Zeng J, Xu Y. A theoretical discussion of the possibility and possible mechanisms of using sesame oil for prevention of 2019-nCoV (COVID-19 coronavirus) from the perspective of colloid and interface science. Research Gate 2020; DOI: 10.13140/RG.2.2.31786.98248.

22. Abbott DJ, Baroody FM, Naureckas E, et al. Elevation of nasal mucosal temperature increases the ability of the nose to warm and humidify air. Am J Rhinol 2001; $15: 41-46$.

23. Saketkhoo K, Januszkiewicz A, Sackner MA. Effects of drinking hot water, cold water, and chicken soup on nasal mucus velocity and nasal airflow resistance. Chest 1978; 74: 408-410.

24. Vathanophas V, Pattamakajonpong P, Assanasen P, et al. The effect of steam inhalation on nasal obstruction in patients with allergic rhinitis. Asian Pac J Allergy Immunol 2019 Jun 4 [Epub ahead of print]. DOI: 10.12932/AP-090818-0393.

25. Kaminsky DA, Guntupalli KK, Lippmann J, et al. Effect of yoga breathing (Pranayama) on exercise tolerance in patients with chronic obstructive pulmonary disease: a randomized, controlled trial. J Altern Complement Med 2017; 23:696-704.

26. Papp ME, Wa nndell PE, Lindfors $P$, et al. Effects of yogic exercises on functional capacity, lung function and quality of life in participants with obstructive pulmonary disease: a randomized controlled study. Eur J Phys Rehabil Med 2017; 53: 447-461.

27. Chopra A, Saluja M, Tillu G. Diet, Ayurveda and interface with biomedicine. J Ayurveda Integr Med 2010; 1: 243-244.
28. Maxwell L, Barrett B, Chase J, et al. Self-reported mental health predicts acute respiratory infection. WMJ 2015; 114: 100.

29. Abel AN, Lloyd LK, Williams JS. The effects of regular yoga practice on pulmonary function in healthy individuals: a literature review. J Altern Complement Med 2013; 19: 185-190.

30. Morgan N, Irwin MR, Chung M, Wang C. The effects of mind-body therapies on the immune system: metaanalysis. PLoS One 2014; 9:e100903.

31. Ministry of AYUSH, Government of India. Ayurveda's immunity boosting measures for self care during COVID 19 crisis. Online document at: http://ayush.gov.in/event/ayurveda-immunity-boostingmeasures-self-care-during-covid-19-crisis, accessed April 10, 2020.

32. Weeks J. COVID-19: NCCIH Director Helene Langevin on the NIH Integrative Center's Response. Online document at: www.johnweeksintegrator.com/uncategorized/covid-19-nccih-directorhelene-langevin-on-the-nih-integrative-centersresponse, accessed April 14, 2020.

33. Weeks J. Call to action: Announcing the traditional, complementary and integrative health and medicine COVID-19 support registry. J Altern Complement Med 2020; 26:256-258.

\section{Source of Support: Nil \\ Conflict of Interest: None Declared}

How to cite this URL: Priyanka et al: Role Of Ayurveda And Yoga For COVID-19. International Ayurvedic Medical Journal \{online\} 2020 \{cited August, 2020\} Available from: http://www.iamj.in/posts/images/upload/4211 4215.pdf 